\title{
The complex response of Arctic aerosol to sea-ice retreat
}

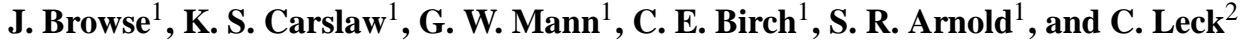 \\ ${ }^{1}$ School of Earth and Environment, University of Leeds, Leeds, UK \\ ${ }^{2}$ Department of Meteorology, Stockholm University, 10691, Stockholm, Sweden
}

Correspondence to: J. Browse (earjbr@leeds.ac.uk)

Received: 31 May 2013 - Published in Atmos. Chem. Phys. Discuss.: 27 June 2013

Revised: 26 February 2014 - Accepted: 23 June 2014 - Published: 29 July 2014

\begin{abstract}
Loss of summertime Arctic sea ice will lead to a large increase in the emission of aerosols and precursor gases from the ocean surface. It has been suggested that these enhanced emissions will exert substantial aerosol radiative forcings, dominated by the indirect effect of aerosol on clouds. Here, we investigate the potential for these indirect forcings using a global aerosol microphysics model evaluated against aerosol observations from the Arctic Summer Cloud Ocean Study (ASCOS) campaign to examine the response of Arctic cloud condensation nuclei (CCN) to sea-ice retreat. In response to a complete loss of summer ice, we find that north of $70^{\circ} \mathrm{N}$ emission fluxes of sea salt, marine primary organic aerosol (OA) and dimethyl sulfide increase by a factor of $\sim 10, \sim 4$ and $\sim 15$ respectively. However, the $\mathrm{CCN}$ response is weak, with negative changes over the central Arctic Ocean. The weak response is due to the efficient scavenging of aerosol by extensive drizzling stratocumulus clouds. In the scavenging-dominated Arctic environment, the production of condensable vapour from oxidation of dimethyl sulfide grows particles to sizes where they can be scavenged. This loss is not sufficiently compensated by new particle formation, due to the suppression of nucleation by the large condensation sink resulting from sea-salt and primary OA emissions. Thus, our results suggest that increased aerosol emissions will not cause a climate feedback through changes in cloud microphysical and radiative properties.
\end{abstract}

\section{Introduction}

Arctic warming has already caused a decline in sea-ice extent over the past quarter century, which has accelerated over the past decade (Comiso, 2002; Boé et al., 2009). Current climate models predict that the late summer Arctic could be nearly ice-free in less than 50 years (Holland et al., 2006) and is likely to be so by 2100 (Boé et al., 2009). The rapidity of Arctic climate change compared to lower latitudes has been attributed to several factors, including the ice-albedo climate feedback (Curry et al., 1995; Flanner et al., 2011).

The ice-albedo feedback can be separated into two aspects described by Curry et al. (1995): (1) the sea-ice-edge-albedo feedback (albedo decrease associated with reductions in horizontal sea-ice extent), and (2) the sea-pack-ice-albedo feedback (albedo decrease associated with internal changes occurring in the multi-year pack ice).

Between 1979 and 2007 the surface global radiative forcing from observed sea-ice retreat (aspect 1) was calculated as $0.1 \mathrm{~W} \mathrm{~m}^{-2}$ (Hudson, 2011; Flanner et al., 2011). This forcing was predicted by Hudson (2011) to increase to $0.3 \mathrm{~W} \mathrm{~m}^{-2}$ assuming zero sea-ice extent in the Arctic for 1 month per year (and diminished extent for the rest of the year). However, in combination with a $15 \%$ increase in Arctic cloudiness the net surface forcing was estimated as $-0.3 \mathrm{~W} \mathrm{~m}^{-2}$. Thus, the significance of the sea-ice-albedo feedback is predicated on the response of Arctic clouds to sea-ice loss and increasing sea surface temperature (SST).

An aerosol-cloud feedback mechanism has been proposed in which a large increase in sea-salt aerosol from an exposed Arctic Ocean increases the atmospheric aerosol optical depth (AOD) and cloud albedo, thereby mitigating the decrease in surface albedo due to sea-ice retreat (Struthers et al., 2010). However, the loss of Arctic sea ice may also increase the source strength of primary biological particles (Bigg and Leck, 2001; Leck and Bigg, 2005; Orellana et al., 2011; Heintzenberg and Leck, 2012) and the aerosol precursor gas dimethyl sulfide (DMS) (Leck and Persson, 1996; Gabric et al., 2005). Intuitively, an increase in the emission of primary aerosol and DMS emission in the Arctic summer 
should cause an increase in aerosol abundance, AOD and cloud condensation nuclei $(\mathrm{CCN})$ concentrations, with associated surface radiative forcings (Hu et al., 2005; Sedlar et al., 2011). Indeed, Struthers et al. (2010) showed that an increase in sea-salt emission in an ice-free Arctic would increase natural aerosol optical depth over the Arctic by $23 \%$, causing a regional direct surface forcing of $-0.3 \pm 0.1 \mathrm{~W} \mathrm{~m}^{-2}$ and a much larger first indirect forcing of $-3 \pm 1 \mathrm{~W} \mathrm{~m}^{-2}$.

An increase in cloudiness is supported by a recent study (Liu et al., 2012) showing that over the period 2000-2010 each $1 \%$ decrease in Arctic sea-ice cover resulted in an increase in cloudiness of $0.3-0.5 \%$. However, the response of Arctic aerosol to reductions in ice cover is uncertain because of insufficient understanding of aerosol sources (Heintzenberg and Leck, 2012) and sinks (Browse et al., 2012) and an inadequate description of these processes in models (Shindell et al., 2008; Korhonen et al., 2008; Birch et al., 2012).

Here, we further investigate this potentially large aerosol indirect forcing by examining the response of Arctic CCN to additional primary aerosol (sea-salt and biological particles) and DMS emissions. We use the Global Model of Aerosol Processes (GLOMAP-mode) (Mann et al., 2010), which has been recently improved to better reproduce summertime aerosol mass observed at high-latitude ground stations (south of $82^{\circ} \mathrm{N}$ ) (Browse et al., 2012). In this study the model is evaluated further against $\mathrm{CCN}$ and aerosol size distribution north of $87^{\circ} \mathrm{N}$ measured during the Arctic Summer Cloud Ocean Study (ASCOS) in the summer of 2008.

\section{Model description}

The model was run at a resolution of $2.8^{\circ} \times 2.8^{\circ}$, with 31 pressure levels extending from the surface to $10 \mathrm{hPa}$. GLOMAP (Mann et al., 2010) uses a two-moment aerosol size-resolving scheme to calculate particle mass and number in seven variable-size log-normal modes (four soluble, three insoluble).

The microphysical processes in GLOMAP include wet (Browse et al., 2012) and dry deposition, ageing of carbonaceous particles from an initial insoluble state to water soluble, oxidation of sulfur dioxide gas $\left(\mathrm{SO}_{2}\right)$ to sulfate in cloud droplets (aqueous phase oxidation), coagulation between (and within) modes, condensation growth (due to uptake of sulfuric acid and secondary organic vapours) and nucleation of $\mathrm{H}_{2} \mathrm{SO}_{4}$ vapour to sulfate aerosol in the boundary layer (BL) and free troposphere (Mann et al., 2010).

GLOMAP utilises multiple sub-time-steps to account for the different timescales over which processes operate. For example, competition between nucleation and condensation is represented by subdividing the microphysics time step ( $\sim 450 \mathrm{~s}$ ) by 5 . During development of GLOMAP both the order of operations and length of operational time steps was tested and found to alter global aerosol number concentrations by less than $5 \%$ (Spracklen et al., 2005).

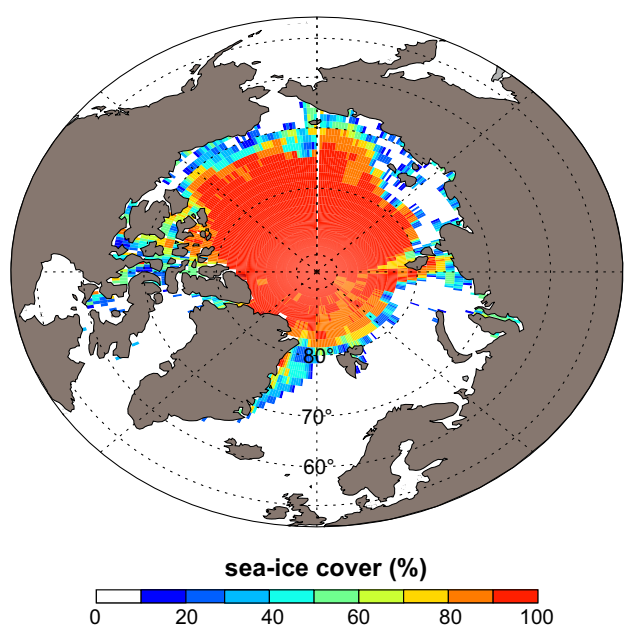

Figure 1. August sea-ice fraction used to scale sea-air fluxes in GLOMAP.

Global emissions of anthropogenic black carbon (BC), organic carbon (OC) and anthropogenic and volcanic $\mathrm{SO}_{2}$ were taken from the Aerosol Comparisons between Observations and Models (AeroCom) hindcast 2006 database (Diehl et al., 2012). Wildfire emissions for 2006 were updated each month from the Global Fire Emissions Database (v2) (van der Werf et al., 2010).

GLOMAP is forced by European Centre for MediumRange Weather Forecasts (ECMWF) 6-hourly global meteorological analyses, which diagnose winds below $6 \mathrm{~m} \mathrm{~s}^{-1}$ for $90 \%$ of the time over the late summer pack ice in 2008, comparing well to observations (Tjernström et al., 2012). Sea-ice cover follows monthly mean data (Rayner, 2003) taken from the British Atmospheric Data Centre (BADC) defined in terms of a grid-box mean sea-ice fraction $\left(F_{\mathrm{SI}}\right)$ (Fig. 1). All marine aerosol and precursor emissions are scaled to $1.0-F_{\mathrm{SI}}$, which we assume encompasses areas of open ocean, sea-ice leads and open polynyas.

The dominant sink for modelled summertime Arctic aerosol is stratocumulus scavenging (Browse et al., 2012). Stratocumulus precipitation (drizzle) rates are calculated from observations of droplet concentration and cloud height and scaled by the coverage fraction of low clouds, resulting in diagnosed drizzle rates between 0.1 and $0.3 \mathrm{~mm} \mathrm{~d}^{-1}$ north of $70^{\circ} \mathrm{N}$. In Browse et al. (2012), where we introduced scavenging of aerosol by drizzle, we showed that high-latitude (north of $70^{\circ} \mathrm{N}$ ) sulfate mass concentrations increased by about a factor of 3 for a halving of drizzle rates. Thus, our baseline simulations are uncertain even before we consider cloud responses to changes in sea ice.

For much of this analysis, 3-D oxidant concentrations are specified every $6 \mathrm{~h}$ from a previous run of the chemical transport model TOMCAT (Toulouse Off-line Model of Chemistry And Transport; Arnold et al., 2005), and thus are uncoupled from dimethyl sulfide (DMS) chemistry. However, 
in Sect. 8.2 we test the sensitivity of the $\mathrm{CCN}$ response to oxidant concentrations by repeating our analysis using the coupled version of GLOMAP (Breider et al., 2010) so that increased DMS concentrations feedback on oxidant concentrations.

\section{Modelling Arctic emissions}

In GLOMAP the sources of summertime Arctic aerosol are (1) transport from lower latitudes, which is substantially suppressed by scavenging in low-level clouds (Browse et al., 2012); (2) particles nucleated in the free troposphere and ultimately transported into the $\mathrm{BL}$; (3) particles nucleated directly in the $\mathrm{BL}$ from $\mathrm{H}_{2} \mathrm{SO}_{4}$ derived from DMS and other sources of $\mathrm{SO}_{2}$ (assumed to follow a nucleation rate $j=$ $A\left[\mathrm{H}_{2} \mathrm{SO}_{4}\right]$ (Kulmala et al., 2006)); (4) wind-driven sea-salt emissions from open leads and the marginal ice zone (MIZ).

Over sea-ice, sea-salt aerosol production from blowing snow could be significantly higher than from the open ocean (Yang et al., 2008). However, the source is negligible at wind speeds below $7 \mathrm{~m} \mathrm{~s}^{-1}$. Thus, for Arctic summertime conditions (Tjernström et al., 2012) neglect of this process in GLOMAP is unlikely to impact our results.

The importance of secondary organic aerosol (SOA) in the Arctic is poorly quantified. Our simulations include SOA from monoterpene emissions (Scott et al., 2014) but neglect other biogenic volatile organic compounds (BVOCs). Measurements at lower Arctic latitudes $\left(70-72^{\circ} \mathrm{N}\right)$ suggest that SOA derived from isoprene and $\alpha$-pinene (excluded from these simulations) comprises $8 \%$ of the identified OC aerosol mass (Fu et al., 2013). However, Fu et al. (2013) report a major portion $(80 \%)$ of measured OC as unidentified (thought to derive from primary marine emission).

Below, we show that the model can simulate a realistic size distribution and CCN population based on existing processes and sources. However, many studies have shown the importance of marine primary organic material (often referred to as biogenic microcolloids or polymer microgels) secreted from phytoplankton, sea-ice algae and bacteria in the ocean mixed layer for Arctic CCN (Orellana et al., 2011; Leck and Bigg, 2005; Bigg and Leck, 2001, 2008). We therefore include a new empirically derived marine primary OC emission flux in GLOMAP (Sect. 3.3).

\subsection{Dimethyl sulfide (DMS) emissions}

DMS seawater concentrations are taken from the inventory of Kettle et al. (1999), which incorporates measurements from the sub-Arctic seas and central Arctic Ocean (Leck and Persson, 1996). The DMS sea-air flux was calculated using the transfer velocity parametrisation of Nightingale et al. (2000), which agrees well with measurements at wind speeds $<10 \mathrm{~m} \mathrm{~s}^{-1}$ (Huebert et al., 2004).
Using year 2000 sea-ice climatologies, the AugustSeptember DMS flux simulated north of $85^{\circ} \mathrm{N}(90$ $100 \%$ pack ice) has an interquartile range of 0.6 $2.68 \mu \mathrm{g} \mathrm{m}^{-2} \mathrm{~d}^{-1} \mathrm{~S}$, which encompasses the observed flux of $0.9 \mu \mathrm{g} \mathrm{m}^{-2} \mathrm{~d}^{-1} \mathrm{~S}$ at $\sim 87^{\circ} \mathrm{N}$ (Leck and Persson, 1996). Modelled DMS emissions from July to September in the MIZ are a factor of $\sim 20$ greater than in the central Arctic Ocean (Fig. 2a), consistent with observations (Leck and Persson, 1996).

In GLOMAP, oxidation of DMS and $\mathrm{SO}_{2}$ to condensable $\mathrm{H}_{2} \mathrm{SO}_{4}$ vapour is driven by $\mathrm{OH}$ and $\mathrm{NO}_{3}$ concentrations (Spracklen et al., 2005). $\mathrm{SO}_{2}$ can add to aerosol mass via several pathways: (1) nucleation of new particles from $\mathrm{H}_{2} \mathrm{SO}_{4}$ vapour (Kulmala et al., 2006), (2) aqueous phase oxidation of $\mathrm{SO}_{2}$ (by $\mathrm{H}_{2} \mathrm{O}_{2}$ and $\mathrm{O}_{3}$ ) in clouds (Mann et al., 2010; Woodhouse et al., 2013) and (3) condensation of $\mathrm{H}_{2} \mathrm{SO}_{4}$ vapour onto the surface of existing aerosol (condensation and ageing processes; Mann et al., 2010). However, only nucleation of new particles from $\mathrm{H}_{2} \mathrm{SO}_{4}$ vapour will add to aerosol number as well as mass. Thus, the efficacy of DMS as an aerosol precursor is dependent on the abundance of oxidants in the Arctic atmosphere and the efficiency and frequency of growth (condensation and wet oxidation) processes.

\subsection{Sea-salt emissions}

The flux of sea-salt aerosol with dry radii 0.0175 to $7 \mu \mathrm{m}$ is calculated using the wind-dependent sea-salt $(\mathrm{NaCl})$ source function of Gong (2003) scaled by sea-ice fraction. The modelled meteorological and sea-ice conditions result in an August sea-salt emission interquartile range of 200 $2300 \mu \mathrm{g} \mathrm{m}^{-2} \mathrm{~d}^{-1} \mathrm{NaCl}$ north of $70^{\circ} \mathrm{N}$. However, emission fluxes greater than $1000 \mu \mathrm{g} \mathrm{m}^{-2} \mathrm{~d}^{-1} \mathrm{NaCl}$ occur exclusively in the marginal ice zone (Fig. 1), with emissions north of $85^{\circ} \mathrm{N}$ ranging from $460-700 \mu \mathrm{g} \mathrm{m}^{-2} \mathrm{~d}^{-1} \mathrm{NaCl}$ (Fig. 2b). GLOMAP has been shown to simulate observed surface level concentrations of sea-salt aerosol at lower latitudes well (Mann et al., 2010), although no similar measurements are available over regions of sea ice.

\subsection{Primary marine organic emissions}

To calculate a primary biological flux of particles we used a similar approach to Lohmann and Leck (2005), adjusting a marine OC flux (ranging from 0.5 to $5.0 \mu \mathrm{m}^{-2} \mathrm{~d}^{-1} \mathrm{OC}$ ) until the observed particle size distribution from the ASCOS observations was reproduced. Marine OC particles were assumed to have a geometric mean diameter of $40 \mathrm{~nm}$ and geometric standard deviation of 1.4 based on measurements in Heintzenberg et al. (2006) and Covert et al. (1996). The best agreement with the observed accumulation mode came from inclusion of an Arctic OC flux (emitted into the Aitken insoluble mode) of $2.85 \mu \mathrm{g} \mathrm{m}^{-2} \mathrm{~d}^{-1} \mathrm{OC}$ (per unit area of open water), which when scaled to $1.0-F_{\text {SI }}(\sim 0.1)$ resulted 


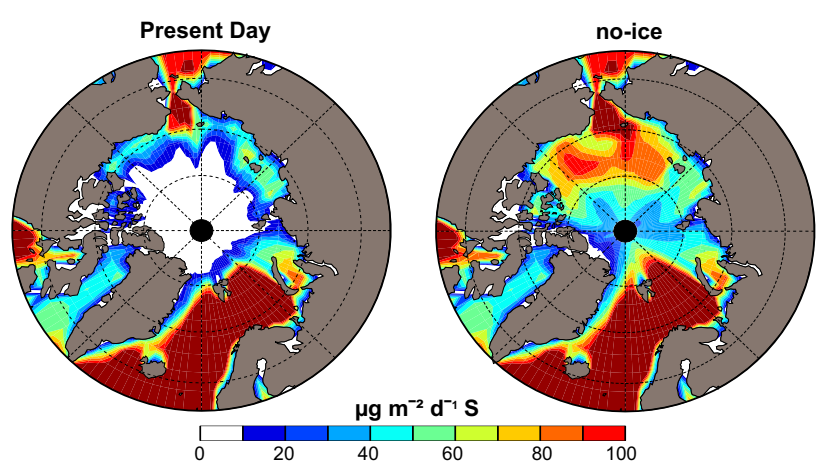

(a) DMS flux

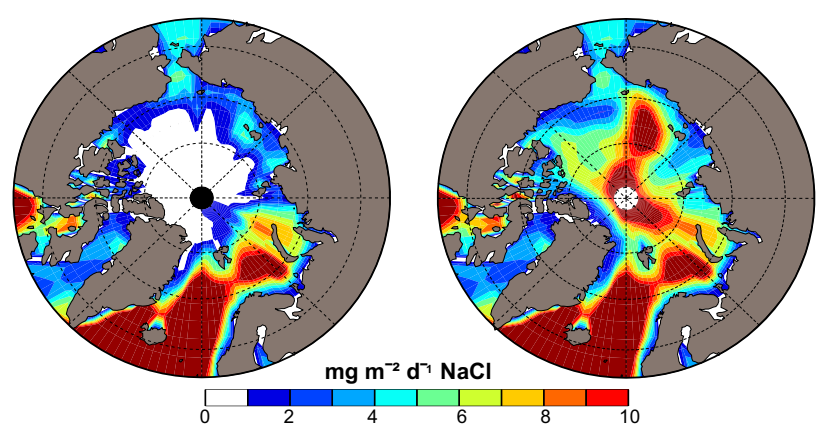

(b) Sea-Salt flux

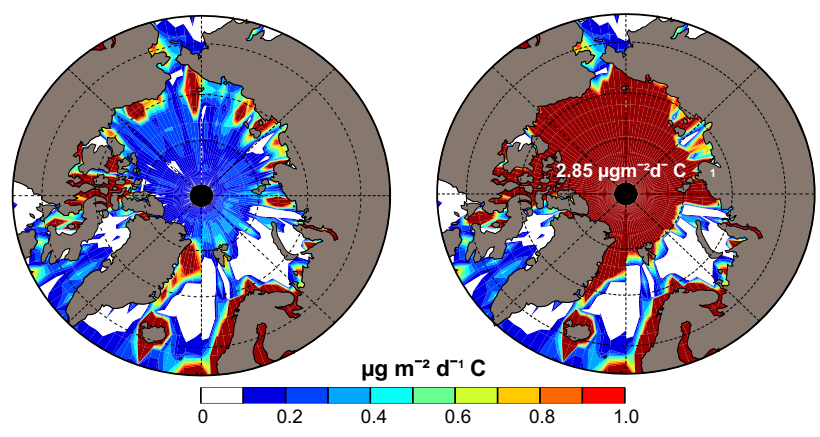

(c) Marine OC flux

Figure 2. (a) Dimethyl sulfide $\left(\mu \mathrm{g} \mathrm{m}^{-2} \mathrm{~d}^{-1} \mathrm{~S}\right)$, (b) primary sea-salt $\left(\mathrm{mg} \mathrm{m}^{-2} \mathrm{~d}^{-1} \mathrm{NaCl}\right)$ and (c) and marine organic carbon $\left(\mu \mathrm{g} \mathrm{m}^{-2} \mathrm{~d}^{-1} \mathrm{C}\right.$ ) flux in the present day (left) and after sea-ice loss (right) (PD and no-ice model runs respectively). As we have not split the primary OC emission tracer, the organic carbon flux shown includes both our derived marine organic sea-surface flux (perturbed by sea-ice loss) and ship emissions (which are identical in each run).

in an August median primary OC flux north of $85^{\circ} \mathrm{N}$ of $0.3 \mu \mathrm{g} \mathrm{m}^{-2} \mathrm{~d}^{-1}$ OC.

\section{Experimental set-up}

Several model simulations were performed to evaluate the model against recent observations and then to quantify the response of aerosol to changes in sea-ice cover. The model was run from 1 August to 30 September 2008 after a 3month spin-up. Monthly mean sea-ice fractions are for the year 2000. The majority of results shown here are for the month of August, although in all instances a similar CCN response to sea-ice loss was seen in July. The four core simulations in the study are defined as follows:

- PD: a present-day control run identical to that presented in Browse et al. (2012), which does not include marine OC emissions.

- PD-MOC: same as PD but with primary marine OC (MOC) emissions from the Arctic Ocean.

- no-ice and no-ice-MOC: same as PD and PD-MOC respectively except that sea-ice fraction in the Northern Hemisphere is set to zero for July, August and September for all model processes.

We also ran several sensitivity cases to test the importance of different processes: PD-noBLN, a present-day run to quantify the importance of boundary layer nucleation (BLN); no-ice[SS], in which the removal of sea ice affects only seasalt emissions; and no-ice[DMS], in which the removal of sea ice affects only DMS emissions.

Further runs also test the importance of drizzle scavenging by suppressing low-cloud precipitation in the present day (PD-noDRIZZ) and after sea-ice loss (no-ice-noDRIZZ). We do not examine the isolated effect of marine organic primary emissions but include the effect of extrapolating the "tuned" OC emission over the entire Arctic Ocean in no-ice-MOC in addition to sea-salt and DMS emission increases. The processes and emission fluxes included in each model run are summarised in Table 1.

\section{The Arctic Summer Cloud Ocean Study (ASCOS)}

The ASCOS ship campaign took place in 2008 between 2 August and 9 September aboard the Swedish icebreaker Oden. The campaign took place in the Arctic Ocean starting in Longyearbyen and included a 3-week measurement period on a drifting ice floe at approximately $87^{\circ} \mathrm{N}$ (Paatero et al., 2009; Tjernström et al., 2014). One purpose of ASCOS was to study the linkage between local aerosol processes and the life cycle of low-level clouds in the shallow Arctic boundary layer. Thus, detailed measurements of boundary layer $\mathrm{CCN}$ and the aerosol size distribution were taken over the majority of the observation period.

During ASCOS, the sub-micron size distribution was measured every $10 \mathrm{~min}$ by a Tandem Differential Mobility Particle Sizer (TDMPS) (Heintzenberg and Leck, 2012). This system consisted of two differential mobility analysers working in parallel over an overlapping size range. Particles were sampled through a $\mathrm{PM}_{10}$ inlet and the size spectra calculated over 45 size bins in the range $3-800 \mathrm{~nm}$. These measurements were found to agree well with a second DMPS system 
Table 1. Summary of processes included in model simulations: $\Delta$ DMS (DMS flux response to sea-ice loss), $\Delta$ SS (sea-salt flux response to sea-ice loss), MOC (primary marine organic flux), $\triangle$ MOC (MOC flux response to sea-ice loss), drizzle (stratocumulus scavenging) and BLN (boundary layer nucleation).

\begin{tabular}{lcccccc}
\hline & $\Delta$ DMS & $\Delta$ SS & MOC & $\Delta$ MOC & drizzle & BLN \\
\hline PD & no & no & no & no & yes & yes \\
PD-MOC & no & no & yes & no & yes & yes \\
PD-noBLN & no & no & no & no & yes & no \\
PD-noDRIZZ & no & no & no & no & no & yes \\
no-ice & yes & yes & no & no & yes & yes \\
no-ice[SS] & no & yes & no & no & yes & yes \\
no-ice[DMS] & yes & no & no & no & yes & yes \\
no-ice-MOC & yes & yes & yes & yes & yes & yes \\
no-ice-noDRIZZ & yes & yes & no & no & no & yes \\
\hline
\end{tabular}

used during the campaign. Further details of this system are discussed in Martin et al. (2011).

Both the DMPS system and CCN counter used the same sampling method. The $\mathrm{PM}_{10}$ inlet mast was situated $25 \mathrm{~m}$ above sea level and protected from local ship pollution by both the position of the inlet and the use of a pollution sensor. A similar method was used for all three previous campaigns in this region (Arctic Ocean experiments, 91, 96, 01) and is discussed in detail in Leck et al. (2001). CCN were measured using two identical CCN counters (Roberts and Nenes, 2005). The first measured $\mathrm{CCN}$ at a fixed supersaturation of $0.2 \%$, while the second cycled between 0.1 and $0.7 \%$ supersaturation. The first instrument was used to measure $\mathrm{CCN}$ number concentrations and the second to determine the sensitivity of measured $\mathrm{CCN}$ to the choice of supersaturation (Mauritsen et al., 2011; Martin et al., 2011).

The modelled and observed size distribution and CCN concentrations were compared as daily means after removing ship-sourced pollution events (similar to in Leck et al., 2001). We restrict our comparison to the period during which the ship was moored to an ice floe at $87^{\circ} \mathrm{N}$ and compare the median size distribution and normalised probability distribution of CCN concentration from 12 August to 1 September 2008 .

\section{Modelling present-day Arctic CCN}

After improvements to the treatment of scavenging in the model, GLOMAP has been shown to simulate realistic sulfate and equivalent $\mathrm{BC}(\mathrm{EBC})$ mass concentrations at Arctic ground stations $\left(<82^{\circ} \mathrm{N}\right)$ well (Browse et al., 2012). However, the indirect aerosol effect depends on CCN concentration changes, not the aerosol component masses. We therefore evaluate the model against $\mathrm{CCN}$ and size distribution measurements over the high-Arctic pack ice from ASCOS. We compare the model against the observations in terms of the size distribution and $\mathrm{CCN}$ frequency histogram (Fig. 3), and quantitatively compare the slope and intercept of modelled and observed integrated particle concentrations between 3 and $800 \mathrm{~nm}$ diameter.

Our present-day (PD) run can explain the median Aitken mode particle concentrations, but predicts too low a number of particles in the accumulation mode (Fig. 3a). In contrast, without BLN (PD-noBLN) the model has extremely low particle concentrations across the full distribution. Thus, in the PD model, BLN is the main source of boundary layer aerosol (Fig. 3) and the contribution of sea-salt particles is insignificant, a result consistent with the analysis of Bigg and Leck (2008).

Comparing the modelled and observed integrated particle concentrations (not shown) gives a slope of 0.96 in the PD run, with an intercept of $60 \mathrm{~cm}^{-3}$, suggesting that the model cannot represent periods of very low aerosol concentrations. This bias is also evident comparing the $\mathrm{CCN}$ frequency histogram for the ice-drift period (Fig. 3b), which suggests that $\mathrm{CCN}$ concentrations are generally overestimated by GLOMAP.

The choice of BLN mechanism in our model is consistent with Karl et al. (2012), who showed that nucleation events observed in the Arctic agree best with a model in which nucleation rates are proportional to $\mathrm{H}_{2} \mathrm{SO}_{4}$ concentrations. Observed nucleation events were characterised by the rapid $(\sim 1 \mathrm{~h})$ enhancement of total particle number (typically $\left.<50 \mathrm{~cm}^{-3}\right)$ to high concentrations $\left(200-1000 \mathrm{~cm}^{-3}\right)$, which persisted between 5 and $12 \mathrm{~h}$. The nucleation rate coefficient (A) used in Karl et al. (2012) is a factor of 10 lower than that used in GLOMAP. Therefore, overestimation of particle number could stem from overestimation of the BLN rate. However, uncertainty analysis of GLOMAP-mode (Lee et al., 2012) suggests that modelled CCN concentrations are fairly insensitive to a factor-of-10 change in the BLN rate. Thus, overestimation of particle number is more likely to stem from interrelated processes such as an underestimation of the Arctic boundary layer $\mathrm{H}_{2} \mathrm{SO}_{4}$ condensation sink.

Reproduction of the observed Aitken mode without BLN was not possible in GLOMAP without significant alterations to model processes or by reducing the size of the OC particles 


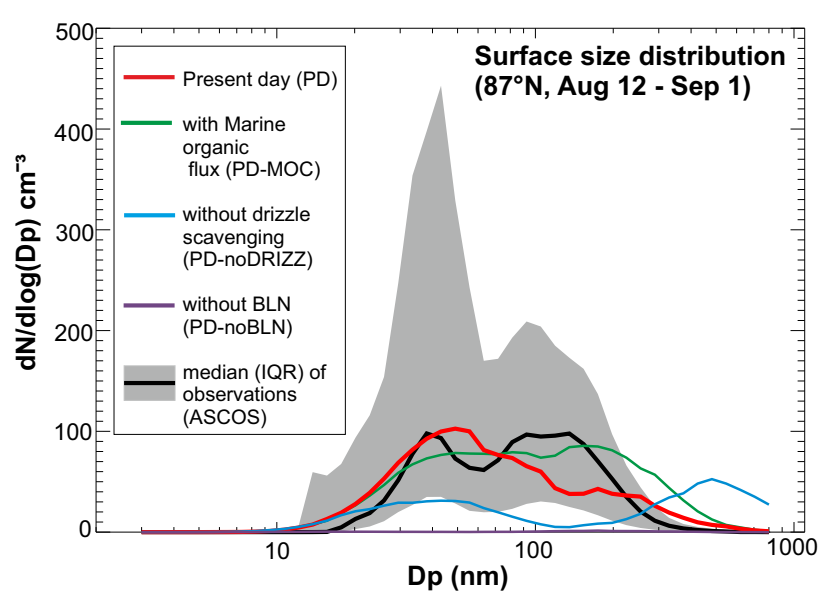

(a) Observed size distribution $\left(87^{\circ} \mathrm{N}, 0-50 \mathrm{~m}\right)$

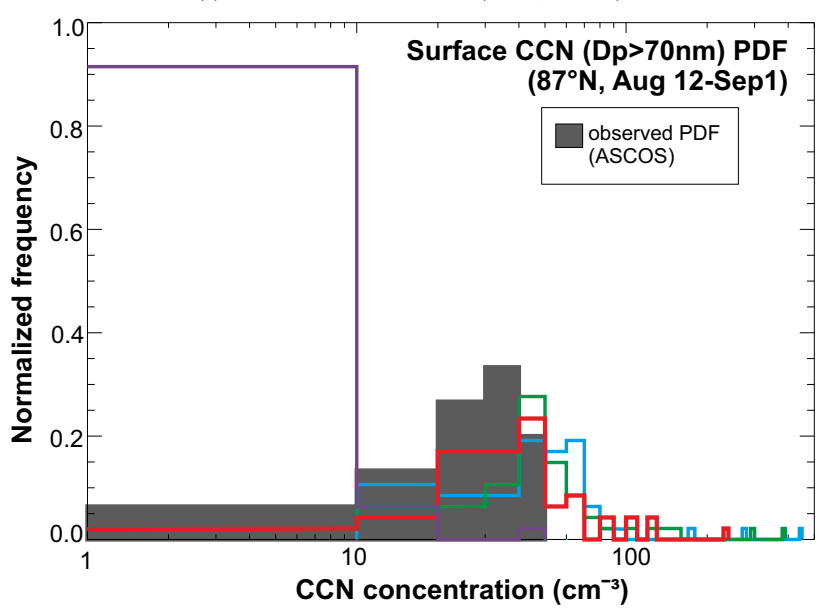

(b) Observed $\mathrm{CCN}$ concentration $\left(87^{\circ} \mathrm{N}, 0-50 \mathrm{~m}\right)$

Figure 3. Model evaluation of high-latitude $\left(87^{\circ} \mathrm{N}\right)$ aerosol against observations from the 2008 ASCOS campaign. (a) shows the median (and interquartile) size distribution observed during the ASCOS ice-drift period (12 August-1 September) compared to (red) a present-day (2008) model run (PD), (purple) a model run without boundary layer nucleation (PD-noBLN), (blue) a model run without stratocumulus (drizzle) scavenging (PD-noDRIZZ) and (green) a model run including our derived marine organic carbon flux (PDMOC). For each run, the modelled size distribution was calculated over the diameter range $3-800 \mathrm{~nm}$ to match the size limitations of the DMPS instrument. (b) shows the probability density function (PDF) of CCN concentration per cubic centimetre observed during the ASCOS ice-drift period (grey), and derived from daily resolved $\mathrm{CCN}$ concentrations from all four model runs described.

to less than $40 \mathrm{~nm}$. Inclusion of the tuned $40 \mathrm{~nm}$ diameter marine OC emissions with BLN (run PD-MOC) improves the agreement with the observed accumulation mode particle number concentration (Fig. 3a). It also improves the total particle concentration model-observation intercept (from 60 to $13 \mathrm{~cm}^{-3}$ ). This $\sim$ fivefold reduction in intercept concentration is a result of the suppression of BLN caused by the higher primary OC surface area.
On balance, we argue that a combination of Aitken primary marine OC emissions and boundary layer nucleation can best explain the observed size distribution and $\mathrm{CCN}$ concentration over the pack ice. But other plausible models cannot be rejected, such as assuming that all Aitken and accumulation mode particles are derived from primary OC (with no BLN), requiring some form of particle disaggregation or altered emission size distribution (Heintzenberg and Leck, 2012).

Finally, we note that our simulations confirm a significant role of drizzle scavenging in controlling modelled Arctic CCN. Suppressing stratocumulus cloud scavenging (PDnoDRIZZ) increases the positive bias in modelled CCN (Fig. 3b), results in a very poor agreement with the observed size distribution (Fig. 3a) and decreases the slope of modelled vs. observed integrated particle concentrations to 0.38 .

\section{Effect of removing sea ice}

\subsection{Changes in emissions of sea salt, DMS and marine $\mathrm{OC}$}

Given the diversity of future predictions of Arctic phytoplankton distribution and species (Gabric et al., 2005) we use the same seawater DMS concentration inventories (extrapolated from observations in the 1990s) (Kettle et al., 1999) for the PD and no-ice runs. DMS emission between 70 and $90^{\circ} \mathrm{N}$ in the no-ice simulation has increased by a factor of 15 from the PD run (Fig. 2a). This increase is greatest north of $85^{\circ} \mathrm{N}$ where the DMS flux in August has increased from a median $2 \mu \mathrm{g} \mathrm{m}^{-2} \mathrm{~d}^{-1} \mathrm{~S}$ to a median $33 \mu \mathrm{g} \mathrm{m}^{-2} \mathrm{~d}^{-1} \mathrm{~S}$ (a factor of $\sim 40$ greater than currently observed; Leck and Persson, 1996). However, the spatial distribution of DMS emission has changed little between the runs (Fig. 2a), with a maximum that continues to occur in the vicinity of Svalbard $>500 \mu \mathrm{g} \mathrm{m}^{-2} \mathrm{~d}^{-1} \mathrm{~S}$.

The removal of sea ice increases the median mass emission of sea-salt aerosol between 70 and $90^{\circ} \mathrm{N}$ by a factor of 10 to $\approx 6000 \mu \mathrm{g} \mathrm{m}^{-2} \mathrm{~d}^{-1} \mathrm{NaCl}$ (approximately one-third that of the North Atlantic). Spatially, maximum sea-salt emission is now in the central Arctic Ocean rather than the Greenland and Barents seas (Fig. 2b). This increase is greater than the factor of 3.5 calculated by Struthers et al. (2010). The difference in sea-salt emission is likely due to a number of factors, such as the use of non-zero sea-ice fraction in Struthers et al. (2010) or differences in the emitted size range.

Predictions of future Arctic marine biological activity with respect to microcolloid production are highly uncertain. The melting of sea ice in general enhances biological activity through various processes (Wassmann and Reigstad, 2011). Thus, for no-ice runs with marine organics (no-ice-MOC) we have extended our derived OC flux over the entire central Arctic Ocean, resulting in a uniform emission in the central and sub-Arctic seas of $2.85 \mu \mathrm{g} \mathrm{m}^{-2} \mathrm{~d}^{-1}$ OC (Fig. 2c), 

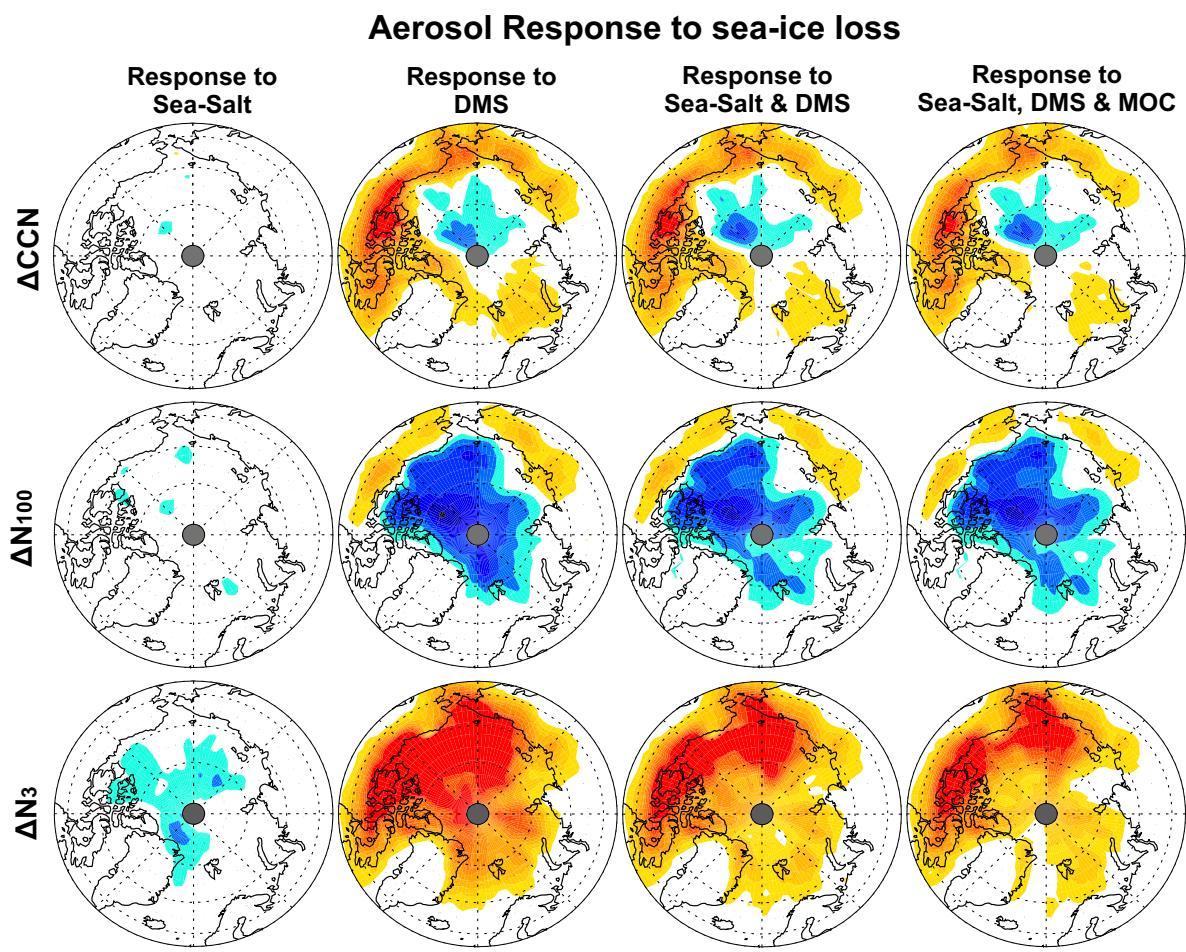

$\%$

Figure 4. Response of modelled surface level aerosol concentrations due to complete loss of sea ice: $\mathrm{CCN}$ (top), $\mathrm{N}_{100}$ (middle) and $\mathrm{N}_{3}$ (bottom). Different aerosols and precursors are allowed to respond to the ice loss: sea-salt flux (column 1), DMS flux (column 2), sea-salt and DMS flux combined (column 3) and all aerosol (sea-salt, DMS and marine organic carbon flux) (column 4).

increasing the median primary OC emission north of $70^{\circ} \mathrm{N}$ by a factor of $\sim 4$ from PD-MOC .

\subsection{Changes in $\mathrm{CCN}$ concentration}

Figure 4 shows the change in August total aerosol $\left(\mathrm{N}_{3}\right)$, $\mathrm{CCN}$ and large aerosol $\left(\mathrm{N}_{100}\right)$ concentration averaged from 0 to $50 \mathrm{~m}$ altitude between PD and after sea-ice loss (noice) (as well as our sensitivity runs no-ice[SS] and noice[DMS], where ice loss has enhanced only sea-salt and DMS emissions respectively). CCN are defined here as particles with diameter $>70 \mathrm{~nm}$, which corresponds approximately to particles activated at $0.2 \%$ supersaturation (to match the ASCOS observations). A supersaturation of $0.2 \%$ is high for Arctic low-level clouds; thus we also present changes in accumulation (and coarse-) mode particle concentrations $\left(\mathrm{N}_{100}\right)$, which corresponds to $\mathrm{CCN}$ activation of particles larger than $100 \mathrm{~nm}$ diameter (geometric mean diameter of 300-400 nm), or a supersaturation of $\sim 0.1 \%$.

Four points stand out from Fig. 4:

- When only sea-salt emissions respond to loss of ice over the Arctic Ocean (Fig. 4, first column), there is a small CCN decrease of less than $10 \%$ and a $5-20 \%$ decrease in $\mathrm{N}_{3}$ concentration (particles larger than $3 \mathrm{~nm}$ ).
- When only DMS emissions respond (Fig. 4, second column) and when both sea-salt and DMS emissions respond (Fig. 4, third column), there is a spatially nonuniform CCN response (10-30\% decrease in the central Arctic Ocean and $>60 \%$ increase in coastal regions) but a uniform increase in $\mathrm{N}_{3}$ concentrations.

- The inclusion of a primary marine OC source in the present day and after ice loss (Fig. 4, fourth column) has not significantly altered the response of Arctic aerosol to sea-ice retreat. However, in some regions (most notably north-west of Svalbard) the response of CCN to ice loss becomes negligible when primary marine $\mathrm{OC}$ emissions are included.

- The decrease in central Arctic CCN is even larger (>50\%) and more widespread when small CCN are excluded $\left(\Delta \mathrm{N}_{100}\right)$. However, coastal $\mathrm{N}_{100}$ concentrations do increase in response to ice loss.

The changes in particle concentration for all simulations are not restricted to the surface layer, but extend up to about $800 \mathrm{hPa}$ (Fig. 5).

In the Arctic summer, in-cloud nucleation scavenging of aerosol by drizzling stratocumulus clouds is the dominant 


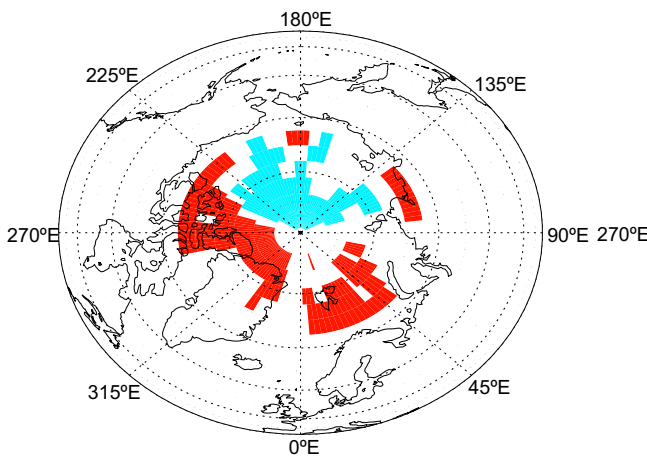

(a) Surface

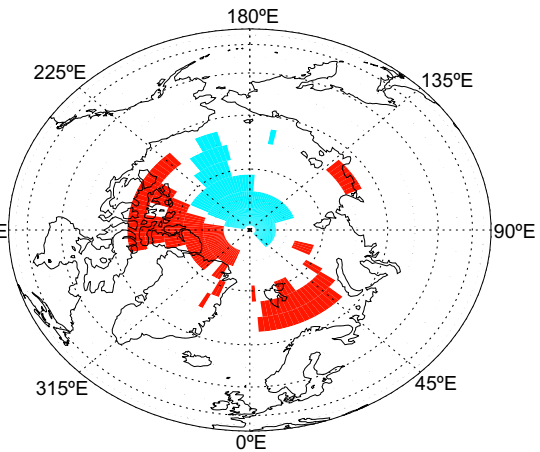

(b) $\sim 900 \mathrm{hPa}$

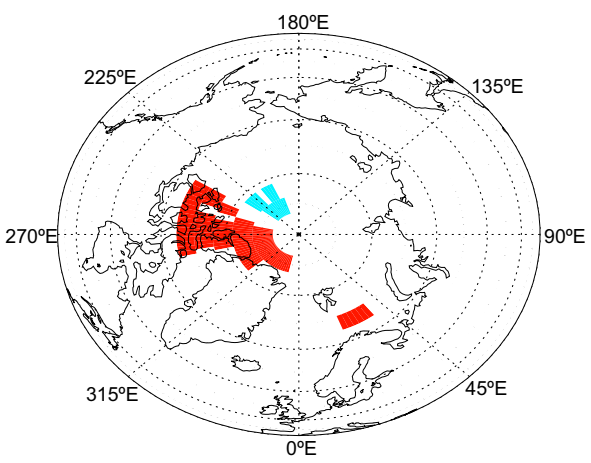

(c) $\sim 800 \mathrm{hPa}$

Figure 5. Map of grid boxes at (a) the surface $(0-50 \mathrm{~m})$, (b) $\sim 900 \mathrm{hPa}(250-350 \mathrm{~m})$ and (c) $\sim 800 \mathrm{hPa}(400-500 \mathrm{~m})$ used to calculate the budget terms shown in Table 2 and the size distributions shown in Fig. 7. Grid boxes with a greater-than-10\% increase in CCN after sea-ice loss are shown in red, while grid boxes with a greater-than-10\% decrease in CCN are shown in blue.

removal process (Browse et al., 2012). Stratocumulus scavenging is therefore likely to be an important factor controlling the response of Arctic aerosol to sea-ice retreat. Figure 6 shows the CCN change in August when stratocumulus cloud scavenging is suppressed in all present-day and ice-loss runs (PD-noDRIZZ and no-ice-noDRIZZ).

Without local wet scavenging, sea-ice loss results in a universal increase in central Arctic CCN (10-20\%), $\mathrm{N}_{100}$ and $\mathrm{N}_{3}$ (10-60\%) concentrations (Fig. 6). However, it must be noted that the significant $\mathrm{CCN}$ increase $(\sim 60 \%)$ over the coastal Canadian Arctic (Fig. 4) is reduced to less than $20 \%$ if we assume a negligible stratocumulus scavenging rate in the model (Fig. 6).

Here, we have shown that in the central Arctic modelled surface concentrations of $\mathrm{CCN}$ decrease after sea-ice retreat. The heterogeneous and non-intuitive response of modelled CCN to additional DMS and primary aerosol (sea-salt and organic) emissions in the Arctic atmosphere is dependent on the strength of local scavenging processes in the Arctic boundary layer. Below we explain this response in terms of competing nucleation and growth (condensation, ageing and aqueous phase oxidation) processes in the scavengingdominated Arctic BL.

\section{Explaining the $\mathrm{CCN}$ response}

Figure 7 shows the size distribution for PD, no-ice, noice[SS] and no-ice[DMS] averaged over grid boxes where $\mathrm{CCN}$ number has either decreased or increased by more than $10 \%$ (Fig. 5). Results are shown for the surface layer (0$50 \mathrm{~m}$ ) and between 250 and $350 \mathrm{~m}$ (where low-cloud fraction is higher, Fig. 8).

When sea-salt emissions alone (without primary organics) respond to ice loss (no-ice[SS]), the number of Aitken and accumulation mode particles decreases (Fig. 7). When DMS emissions alone respond to ice loss (no-ice[DMS]), the Aitken mode particle concentrations increase and accumulation mode concentrations decrease. The combined effect of changes in sea spray and DMS is to increase the size and number concentration of the Aitken mode everywhere but decrease the number of accumulation mode particles. Thus, $\mathrm{CCN}$ concentrations decrease in regions where the increase in large (>70 nm diameter) Aitken particles is insufficient to compensate for the loss of accumulation mode particles (Fig. 7). This response is the same at $900 \mathrm{hPa}$. However, within the cloud layer (Fig. 8) the response to sea-salt emissions alone is reduced (Fig. $7 \mathrm{c}-\mathrm{d}$ ). 
Aerosol Response to sea-ice loss (drizzle scavenging suppressed)
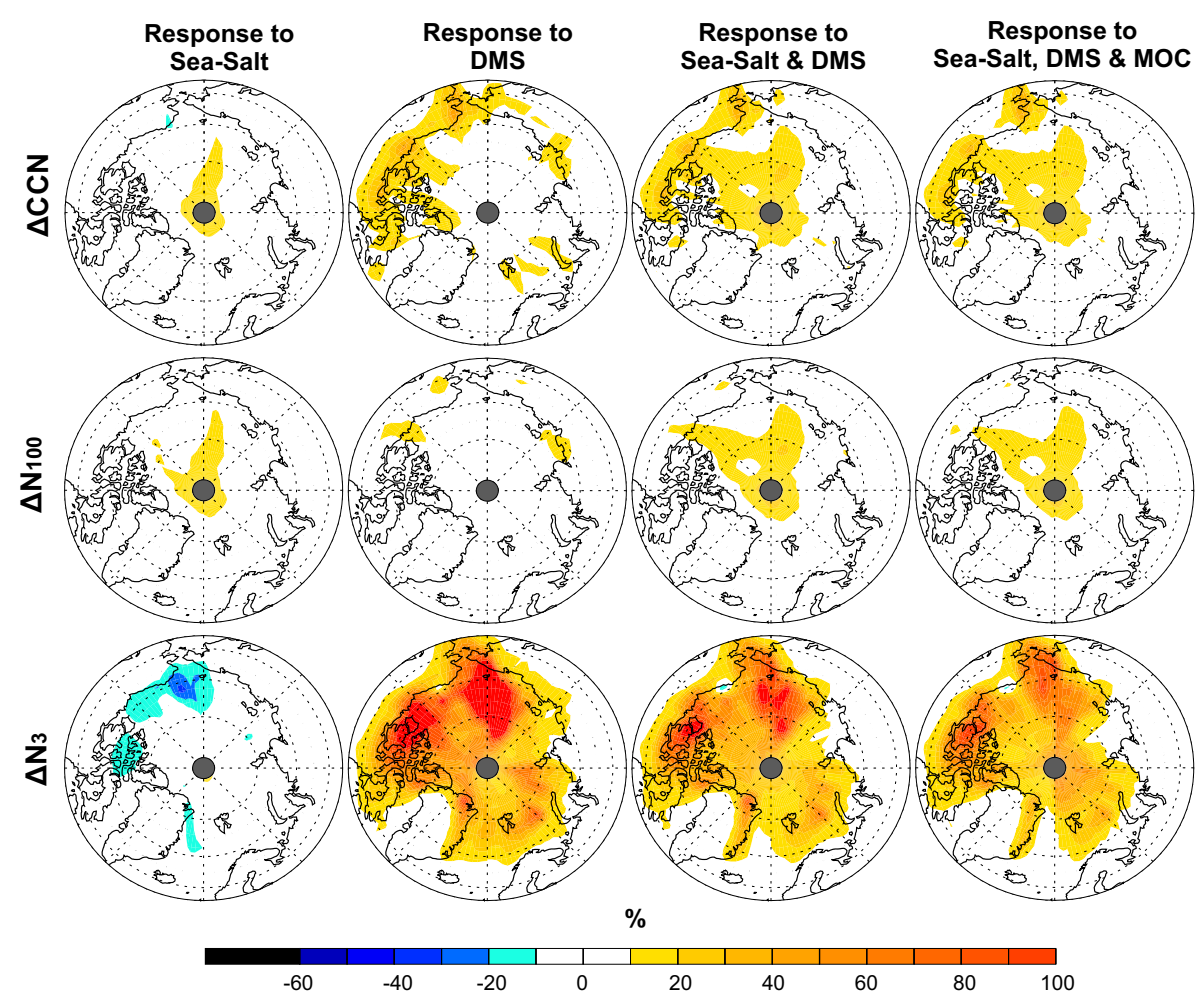

Figure 6. Response of modelled surface level aerosol concentrations due to complete loss of sea ice in a model run without drizzle: CCN (top), $\mathrm{N}_{100}$ (middle) and $\mathrm{N}_{3}$ (bottom). Different aerosols and precursors are allowed to respond to the ice loss: sea-salt flux (column 1), DMS flux (column 2), sea-salt and DMS flux combined (column 3) and all aerosol (sea-salt, DMS and marine organic carbon flux) (column 4).

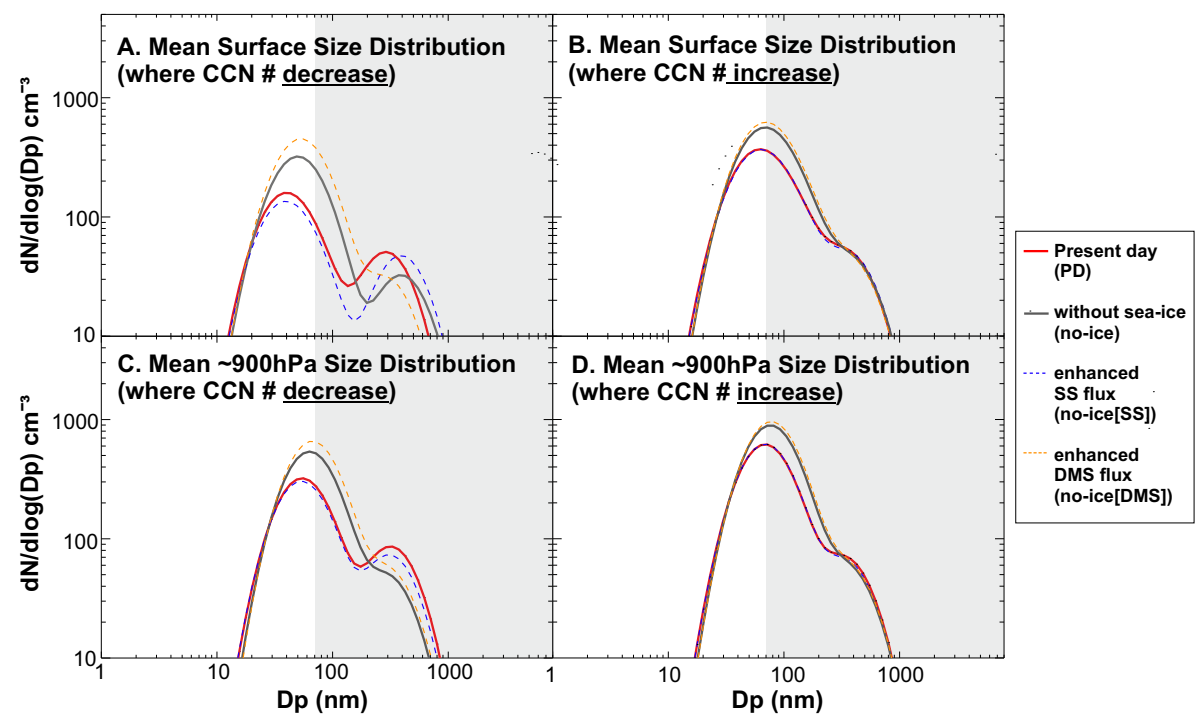

Figure 7. Average August size distribution for model grid boxes where CCN concentrations decrease in response to sea-ice loss (A, C) and increase in response to sea-ice loss (B, D). Grid boxes included in the analysis are shown in Fig. 5. Analysis is shown for the surface (A, B) and the cloud level (C, D) for (in red) the present day (PD), (in grey) after sea-ice loss (no-ice), (in blue) with enhanced SS flux only (no-ice[SS]) and (in orange) with enhanced DMS flux only (no-ice[DMS]). 


\section{Low Cloud Fraction}

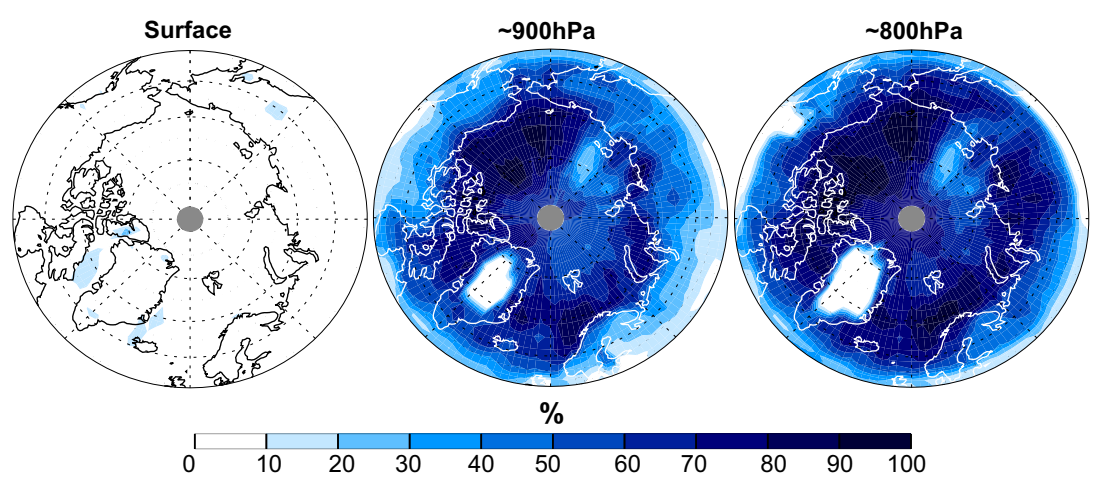

Figure 8. Low cloud fraction used in GLOMAP at the surface $(0-50 \mathrm{~m}), \sim 900 \mathrm{hPa}(250-350 \mathrm{~m})$ and $\sim 800 \mathrm{hPa}(400-500 \mathrm{~m})$.

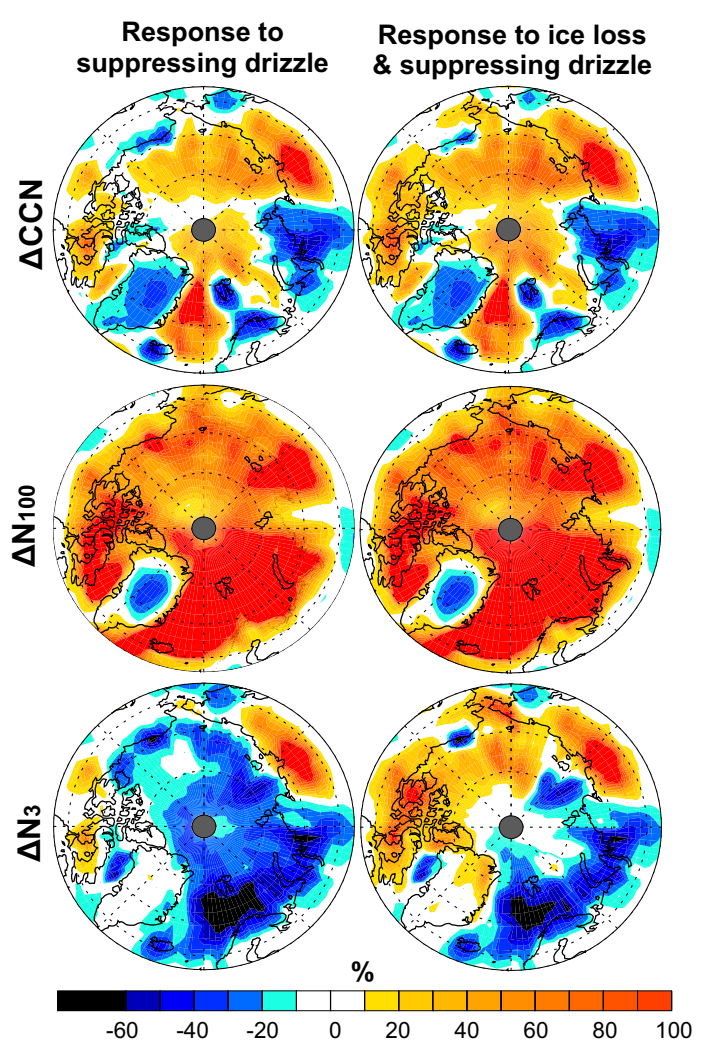

Figure 9. Response of modelled surface level aerosol concentrations due to suppression of drizzle (left column) and the combined effect of suppression of drizzle and loss of sea ice (right column): $\mathrm{CCN}$ (top), $\mathrm{N}_{100}$ (middle) and $\mathrm{N}_{3}$ (bottom). These simulations with sea-ice loss differ from those in Fig. 6 where drizzle is switched off in all runs. Here, drizzle is switched off only when sea ice is suppressed to represent a possible side effect of the enhanced aerosol sources on precipitation.
Table 2 shows the percentage change in nucleation, condensation, aqueous phase oxidation, ageing and sulfate scavenging fluxes for regions where $\mathrm{CCN}$ have decreased after sea-ice loss. In regions where $\mathrm{CCN}$ decrease, nucleation rates fall by $50 \%$ when only sea spray responds (no-ice[SS]), increase by $60 \%$ when both DMS and sea spray respond (noice) and increase by $\sim 400 \%$ when only DMS responds to ice loss (no-ice[DMS]). Sea spray therefore strongly suppresses nucleation and DMS strongly enhances it, leading to a small net enhancement in nucleation when both DMS and sea spray respond to ice loss.

The decrease in nucleation rates in response to additional sea spray is an effect of increasing the condensation sink in a strongly scavenging environment. When we increase the surface level condensation sink (sea-spray response to seaice loss) but maintain present-day DMS concentrations (as in no-ice[SS]), the nucleation flux decreases (50\%) but the condensation flux increases $(\sim 30 \%)$. This response results in a decrease in total particle number $\left(\mathrm{N}_{3}\right)$ (Fig. 7a), an increase in particle size and a $10 \%$ increase in scavenged accumulation mode sulfate because larger particles are more efficiently scavenged (Table 2).

We propose that the modelled response of $\mathrm{CCN}$ to sea-ice loss can be explained by the interaction of several competing processes in the Arctic boundary layer, in terms of changes in the particle size distribution (Fig. 7):

1. More sea-salt aerosol alone leads to reduced $\mathrm{CCN}$ because it acts to suppress an important source of CCN - boundary layer nucleation. The suppression of nearsurface nucleation $(-50 \%)$ is evident in the reduction in $\mathrm{N}_{3}$ in Fig. 4. At the same time sea-salt aerosol itself does not add significantly to $\mathrm{CCN}$ as it is strongly scavenged (evident in the negligible size distribution changes at cloud level between PD and no-ice[SS]).

2. More DMS alone can cause a reduction in $\mathrm{CCN}$ because the increase in $\mathrm{H}_{2} \mathrm{SO}_{4}$ grows all particles to sizes where they can be wet-scavenged more easily (Table 2 ). In 
Table 2. Change in nucleation (Nucl.), condensation (Cond.), aqueous phase oxidation (Wet ox.), ageing (Age), accumulation mode scavenging (Acc. wet dep.) and Aitken mode scavenging (Ait. wet dep.) flux between the present day and our ice-loss scenarios (no-ice, no-ice[SS] and no-ice[DMS]). We also show the present-day absolute value of each metric (column 1). Our average flux is calculated over grid boxes where the CCN response to sea-ice loss is less than $-10 \%$ (Fig. 5). Note: the same grid boxes are used to derive an average flux in all runs. Thus, the response of modelled microphysical processes from the no-ice[SS] and no-ice[DMS] runs does not necessarily reflect a CCN response of less than $-10 \%$.

\begin{tabular}{|c|c|c|c|c|c|c|c|c|}
\hline \multirow[b]{3}{*}{ Altitude (m) } & \multirow{2}{*}{\multicolumn{2}{|c|}{ PD }} & \multicolumn{6}{|c|}{$\Delta$ from PD, present-day sea ice $(\%)$} \\
\hline & & & \multicolumn{2}{|c|}{ no-ice } & \multicolumn{2}{|c|}{ no-ice $[S S]$} & \multicolumn{2}{|c|}{ no-ice[DMS] } \\
\hline & $0-50$ & $250-350$ & $0-50$ & $250-350$ & $0-50$ & $250-350$ & $0-50$ & $250-350$ \\
\hline Nucl. $\left(\right.$ ngm $\left.^{-3} \mathrm{~d}^{-1} \mathrm{~S}\right)$ & 0.001 & 0.0001 & 60 & 180 & -54 & -57 & 390 & 350 \\
\hline Cond. $\left(\operatorname{ngm}^{-3} \mathrm{~d}^{-1} \mathrm{~S}\right)$ & 0.02 & 0.005 & 350 & 220 & 26 & -8 & 240 & 260 \\
\hline Wet ox. $\left(\right.$ ngm $\left.^{-3} \mathrm{~d}^{-1} \mathrm{~S}\right)$ & 0.2 & 5 & 120 & 240 & -0.5 & -0.5 & 120 & 240 \\
\hline Age. $\left(\operatorname{ngm}^{-3} \mathrm{~d}^{-1} \mathrm{~S}\right)$ & 0.001 & 0.0004 & 180 & 320 & -15 & -1 & 250 & 330 \\
\hline Ait. wet dep. $\left(\right.$ ngm $\left.^{-2} \mathrm{~d}^{-1} \mathrm{~S}\right)$ & \multicolumn{2}{|c|}{0.04} & \multicolumn{2}{|c|}{120} & \multicolumn{2}{|r|}{-5} & \multicolumn{2}{|r|}{200} \\
\hline Acc. wet dep. $\left(\right.$ ngm $\left.^{-2} \mathrm{~d}^{-1} \mathrm{~S}\right)$ & \multicolumn{2}{|c|}{1625} & \multicolumn{2}{|c|}{150} & \multicolumn{2}{|r|}{10} & \multicolumn{2}{|r|}{140} \\
\hline
\end{tabular}

the central Arctic this effect is only partly offset by increased boundary layer nucleation (evident in the large increase in $\mathrm{N}_{3}$ in Fig. 4).

3. A combination of DMS, OC and sea salt accelerates the growth of primary particles (increasing the scavenging rate) while simultaneously suppressing nucleation due to a higher condensation sink near the surface. In regions away from the sea-salt source, such as over the continental Canadian Arctic (Fig. 2b), this response is more than compensated for by the enhanced supply of $\mathrm{CCN}$ from boundary layer nucleation.

Finally, our results suggest that aqueous phase oxidation within cloud droplets (wherein $\mathrm{SO}_{2}$ reacts with $\mathrm{OH}$ in cloud droplets to form $\mathrm{H}_{2} \mathrm{SO}_{4}$ ) is a significant sink for Arctic DMS (Table 2), which increases in a no-ice scenario by $\sim 200 \%$. Thus, the impact of DMS emissions on CCN is suppressed due to existing boundary layer clouds, a result consistent with the analysis of Woodhouse et al. (2013), who suggest that the inefficiency of the DMS climate feedback (or CLAW mechanism) (Leck and Bigg, 2008; Quinn and Bates, 2011; Woodhouse et al., 2010) stems from the efficient oxidation processes which suppress new particle formation in the remote marine boundary layer.

Our results are plausible in terms of microphysical effects. The impact of the condensation sink on Arctic nucleation events has been noted in observations by Rempillo et al. (2011), which linked new particle formation (from DMSderived $\mathrm{H}_{2} \mathrm{SO}_{4}$ ) to clear-sky conditions. However, our simulations neglect the possible effects of aerosols on cloud microphysics and precipitation.

\subsection{Response of $\mathrm{CCN}$ to precipitation suppression}

In these simulations we have assumed that the change in aerosol emissions has no effect on cloud microphysics. How- ever, complex microphysical responses of Arctic shallow clouds cannot be excluded. We can project two scenarios: (1) enhanced aerosol and precursor emissions suppress precipitation, or (2) a large increase in latent heat flux increases precipitation.

As an extreme case we can quantify the response of $\mathrm{CCN}$ to sea-ice loss assuming that the extra aerosol suppresses all precipitation. In this scenario (1) the removal of ice leads to significant increases in central Arctic $\mathrm{CCN}$ concentrations (10-40\%), while in some more southerly regions CCN decrease (Fig. 9, top). Figure 9 shows that the aerosol response to ice loss combined with drizzle suppression is very similar to the response of CCN to drizzle suppression alone. The explanation lies in the role of drizzle in scavenging aerosol transported from lower latitudes (Browse et al., 2012). When drizzle is suppressed in the no-ice run, Arctic aerosol becomes dominated by $\mathrm{N}_{100}$ particles transported from low latitudes (Fig. 9, middle), which is the same aerosol that flows into the Arctic when drizzle is suppressed in the present day.

If precipitation were to increase (scenario 2), the negative response of $\mathrm{CCN}$ (and $\mathrm{N}_{100}$ ) concentrations to enhanced seasalt aerosol and DMS is unlikely to change with larger particles more quickly scavenged. In addition, we would expect a decrease in transport from lower latitudes further depleting $\mathrm{N}_{100}$ concentrations in the high Arctic.

Both scenarios are plausible. However, given our poor understanding of Arctic clouds, any model response is speculative and our analysis points to the need for a much better understanding of aerosol-cloud interaction in the Arctic.

\subsection{Oxidant limitations}

CCN change in GLOMAP after sea-ice loss is driven by the increase in DMS emission. However, the rate of $\mathrm{SO}_{2}$ formation from DMS is dependent on the availability of oxidants 
in the Arctic boundary layer (Voulgarakis et al., 2009). The previous analysis was performed with the uncoupled version of GLOMAP, which used fixed oxidant fields (including $\mathrm{HO}_{\mathrm{x}}$ and $\mathrm{NO}_{\mathrm{x}}$ ) from Arnold et al. (2005). Thus, the feedback from increasing DMS concentrations on the abundance of oxidants was neglected.

Similar analysis using a coupled version of the model (Breider et al., 2010) shows an identical aerosol response to that shown in Fig. 4. This result suggests that oxidant concentrations do not limit the response of CCN to DMS emissions in GLOMAP. However, these simulations do not include the reduction in photolysis rates driven by surface albedo change from sea-ice loss, which could decrease $\mathrm{OH}$ concentrations by $30-60 \%$ (Voulgarakis et al., 2009), or the effect of sea-ice retreat on bromine chemistry.

Bromine has been shown to contribute $\sim 20 \%$ (maximum $40 \%$ ) to the DMS sink at high latitudes (Breider et al., 2010). High-latitude bromine radicals $(\mathrm{Br}, \mathrm{BrO})$ derive from photochemical reactions within the snowpack (Pratt et al., 2013), blowing snow events (Yang et al., 2008) and frost flowers (Foster et al., 2001). Thus, sea-ice retreat will likely decrease $\mathrm{BrO}$ abundance, although the impact of ice loss on bromine sources is unquantified. The sensitivity of Arctic aerosol to either $\mathrm{BrO}$ or $\mathrm{OH}$ abundance has not been tested here. However, if oxidant concentrations decrease, then the aerosol response to summertime sea-ice retreat could be dominated by primary emissions (i.e the response of aerosol to no-ice[SS]) and, thus, negligible.

\section{Conclusions}

Before the end of this century, significant retreat of Arctic sea ice is likely to affect many aspects of the Arctic and global climate, including aerosol characteristics. In this study, the total removal of sea ice from July to September increased emission of sea salt, marine primary organic aerosol and DMS north of $70^{\circ} \mathrm{N}$ in GLOMAP by a factor of $\sim 10, \sim 4$ and $\sim 15$ respectively. The combined increase in primary aerosol and DMS emission increased total particle concentrations by $30-40 \%$ north of $80^{\circ} \mathrm{N}$. However, the change in $\mathrm{CCN}$ was non-uniform, with significant increases over the continental Arctic and small decreases over the central Arctic Ocean (Fig. 4).

Analysis of the modelled size distribution (Fig. 7) and relative change in nucleation rate (Table 2) suggests that this spatially non-uniform $\mathrm{CCN}$ response is the result of enhanced growth and nucleation processes from the additional DMSderived sulfuric acid vapour, competing in a strongly scavenging environment. Where the boundary layer condensation sink is large, such as over the open Arctic Ocean with enhanced sea spray, nucleation is suppressed. In this environment, particles grow to sizes where they are more readily scavenged, leading to a reduction in accumulation mode particle concentrations. However, over continental regions with- out an enhanced sea-salt flux, nucleation processes dominate and particle concentrations increase (Fig. 4).

These modelled responses are plausible in terms of microphysical effects, but our study also highlights the significant uncertainties that remain in trying to quantify aerosol-cloud processes in the poorly understood Arctic system. In particular we have assumed that the aerosol system responds to loss of ice but that atmospheric dynamics and clouds remain unchanged. It is also plausible that the enhanced aerosol sources suppress Arctic drizzle, which would allow more efficient transport of aerosol into the Arctic from low latitudes (resulting in a positive Arctic aerosol feedback in some regions). Alternatively, the predicted growth of the marginal ice zone and decline of multi-year sea ice could result in a rise in local humidity and other meteorologically driven changes in cloud processes (Vavrus et al., 2011). Thus, the impact of any $\mathrm{CCN}$ change on the radiative characteristics of clouds must be quantified relative to the impact of higher Arctic humidity.

This work highlights the complexity of processes controlling high-Arctic summer aerosol size distribution and CCN concentration. Our results indicate that the $\mathrm{CCN}$ response to sea-ice loss is controlled by many interrelated processes. It is unlikely that present global climate models include an adequate representation of any of these aerosol-cloud and boundary layer processes to simulate long-term changes with any fidelity. Thus, we suggest that for aerosol-cloud-climate feedbacks in the Arctic to be projected we must first address the significant gap in our understanding of polar aerosol and cloud processes.

Acknowledgements. J. Browse was funded by a studentship from the Natural Environment Research Council (NERC) and by the Met Office through a CASE partnership. K. S. Carslaw is a Royal Society Wolfson Merit Award holder. G. W. Mann is funded by the Natural Environment Research Council. We would like to thank Anja Scmidt and Matthew Woodhouse for their comments and assistance. This work is part of ASCOS (the Arctic Summer Cloud Ocean Study). ASCOS was made possible by funding from the Knut and Alice Wallenberg Foundation and the DAMOCLES European Union 6th Framework Programme Integrated Research Project. The Swedish Polar Research Secretariat (SPRS) provided access to the icebreaker Oden and logistical support. Michael Tjernström and C. Leck are specifically thanked for their coordination of ASCOS. We are grateful to the SPRS logistical staff and to Oden's captain, Mattias Peterson, and his crew. ASCOS is an IPY project under the AICIA-IPY umbrella and an endorsed SOLAS project. Support for this work was provided by the Swedish Research Council (VR) and the Knut and Alice Wallenberg Foundation. The research was also supported with funding from the EU FP7 project BACCHUS under grant agreement 603445-BACCHUS and the NERC ACCACIA project (NE/I028858/1).

Edited by: U. Pöschl 


\section{References}

Arnold, S., Chipperfield, M., and Blitz, M.: A three-dimensional model study of the effect of new temperature-dependent quantum yields for acetone photolysis, J. Geophys. Res., 110, D22305, doi:10.1029/2005JD005998, 2005.

Bigg, E. K. and Leck, C.: Properties of aerosol over the Central Arctic Ocean, J. Geophys. Res., 106, 32101-32109, doi:10.1029/1999JD901136, 2001.

Bigg, E. K. and Leck, C.: The composition of fragments of bubbles bursting at the ocean surface, J. Geophys. Res., 113, D11209, doi:10.1029/2007JD009078, 2008.

Birch, C. E., Brooks, I. M., Tjernström, M., Shupe, M. D., Mauritsen, T., Sedlar, J., Lock, A. P., Earnshaw, P., Persson, P. O. G., Milton, S. F., and Leck, C.: Modelling atmospheric structure, cloud and their response to $\mathrm{CCN}$ in the central Arctic: ASCOS case studies, Atmos. Chem. Phys., 12, 3419-3435, doi:10.5194/acp-12-3419-2012, 2012.

Boé, J., Hall, A., and Qu, X.: September sea-ice cover in the Arctic ocean projected to vanish by 2100 , Nat. Geosci., 2, 341-343, 2009

Breider, T. J., Chipperfield, M. P., Richards, N. A. D., Carslaw, K. S., Mann, G. W., and Spracklen, D. V.: Impact of BrO on dimethylsulfide in the remote marine boundary layer, Geophys. Res. Lett., 37, L02807, doi:10.1029/2009GL040868, 2010.

Browse, J., Carslaw, K. S., Arnold, S. R., Pringle, K., and Boucher, O.: The scavenging processes controlling the seasonal cycle in Arctic sulphate and black carbon aerosol, Atmos. Chem. Phys., 12, 6775-6798, doi:10.5194/acp-12-6775-2012, 2012.

Comiso, J.: A rapidly declining perennial sea ice cover in the Arctic, Geophys. Res. Lett., 29, 1956, doi:10.1029/2002GL015650, 2002.

Covert, D. S., Weidensohler, A., Aalto, P. P., Heintzenberg, J., McMurry, P. H., and Leck, C.: Aerosol number size distributions from 3 to $500 \mathrm{~nm}$ diameter in the Arctic marine boundary layer during summer and autumn, Tellus, 48B, 197-212, 1996.

Curry, J. A., Schramm, J. L., and Ebert, E. E.: Sea ice-albedo climate feedback mechanism, J. Climate, 8, 240-247, 1995.

Diehl, T., Heil, A., Chin, M., Pan, X., Streets, D., Schultz, M., and Kinne, S.: Anthropogenic, biomass burning, and volcanic emissions of black carbon, organic carbon, and $\mathrm{SO}_{2}$ from 1980 to 2010 for hindcast model experiments, Atmos. Chem. Phys. Discuss., 12, 24895-24954, doi:10.5194/acpd-12-24895-2012, 2012.

Flanner, M. G., Shell, K. M., Barlage, M., Perovich, D. K., and Tschudi M. A.: Radative forcing and albedo feedback from the Northern Hemisphere cryosphere between 1979 and 2008, Nat. Geosci., 4, 151-155, doi:10.1038/ngeo1062, 2011.

Foster, K. L., Plastridge, R. A., Bottenheim, J. W., Shepson, P. B., Finlayson-Pitts, B. J., and Spicer, C. W.: The Role of Br2 and $\mathrm{BrCl}$ in Surface Ozone Destruction at Polar Sunrise, Science, 291, 471-474, doi:10.1126/science.291.5503.471, 2001.

Fu, P. Q., Kawamura, K., Chen, J., Charrière, B., and Sempéré, R.: Organic molecular composition of marine aerosols over the Arctic Ocean in summer: contributions of primary emission and secondary aerosol formation, Biogeosciences, 10, 653-667, doi:10.5194/bg-10-653-2013, 2013.

Gabric, A. J., Qu, B., Matrai, P., and Hirst, A. C.: The simulated response of dimethylsulphide production in the Arctic Ocean to global warming, Tellus, 57B, 391-403, 2005.
Gong S. L.: A parameterization of sea-salt aerosol source function for sub- and super-micron particles, Global Biogeochem. Cy., 17, 8-16, doi:10.1029/2003GB002079, 2003.

Heintzenberg, J. and Leck, C.: The summer aerosol in the central Arctic 1991-2008: did it change or not?, Atmos. Chem. Phys., 12, 3969-3983, doi:10.5194/acp-12-3969-2012, 2012.

Heintzenberg, J., Leck, C., Birmili, W., Wehner, B., Tjernström, M., and Weidensohler A.: Aerosol number size-distributions during clear and fog periods in the summer high Arctic; 1991, 1996 and 2001, Tellus, 58B, 41-50, 2006.

Holland, M. M., Bitz, C. M., and Tremblay, B.: Future abrupt reductions in the summer Arctic sea ice, Geophys. Res. Lett, 33, L23503, doi:10.1029/2006GL028024, 2006.

Hu, R.-M., Blanchet, J.-P., and Girard, E.: Evaluation of the direct and indirect radiative and climate effects of aerosols over the western Arctic, J. Geophys. Res, 110, D112213, doi:10.1029/2004JD005043, 2005.

Hudson, S. R.: Estimating the global radiative impact of the sea icealbedo feedback in the Arctic, J. Geophys. Res., 116, D16102, doi:10.1029/2011JD015804, 2011.

Huebert, B. J., Blomquist, B. W., Hare, J. E., Fairall, C. W., Johnson, J. E., and Bates, T. S: Measurements of the sea-air DMS flux and transfer velocity using eddy correlation, Geophys. Res. Lett., 31, L23113, doi:10.1029/2004GL021567, 2004.

Karl, M., Leck, C., Gross, A., and Pirjola, L.: A study of new particle formation in the marine boundary layer over the central Arctic Ocean using a flexible multicomponent aerosol dynamic model, Tellus, 64, 17158, doi:10.3402/tellusb.v64i0.17158, 2012.

Kettle, A. J., Andreae, M. O., Amouroux, D., Andreae, T. W., Bates, T. S., Berresheim, H., Bingemer, H., Boniforti, R., Curran, M. A. J., DiTullio, G. R., Helas, G., Jones, G. B., Keller, M. D., Kiene, R. P., Leck, C., Levasseur, M., Malin, G., Maspero, M., Matrai, P., McTaggart, A. R., Mihalopoulos, N., Nguyen, B. C., Novo, A., Putaud, J. P., Rapsomanikis, S., Roberts, G., Schebeske, G., Sharma, S., Simo, R., Staubes, R., Turner, S., and Uher, G.: A global database of sea surface dimethylsulfide (DMS) measurements and a procedure to predict sea surface DMS as a function of latitude, longitude and month, Global Biogeochem. Cy., 13, 399-444, doi:10.1029/1999GB900004, 1999.

Korhonen, H., Carslaw, K. S., Spracklen, D. V., Ridley, D. A., and Ström, J.: A global model study of processes controlling aerosol size distributions in the Arctic spring and summer, J. Geophys. Res., 113, D8, doi:10.1029/2007JD009114, 2008.

Kulmala, M., Lehtinen, K. E. J., and Laaksonen, A.: Cluster activation theory as an explanation of the linear dependence between formation rate of $3 \mathrm{~nm}$ particles and sulphuric acid concentration, Atmos. Chem. Phys., 6, 787-793, doi:10.5194/acp-6-787-2006, 2006.

Leck, C. and Bigg, E. K.: Biogenic particles in the surface microlayer and overlaying atmosphere in the central Arctic Ocean during summer, Tellus, 57B, 305-316, 2005.

Leck, C. and Bigg, E. K.: A modified aerosol-cloudclimate-feedback hypothesis, Environ. Chem., 4, 400-403, doi:10.1071/EN07061, 2008.

Leck, C. and Persson, C.: The central Arctic Ocean as a source of dimethyl sulfide - Seasonal variability in relation to biological activity, Tellus, 48B, 156-177, 1996.

Leck, C., Nilsson, E. D., Biggs K., and Bäcklin, L.: The Atmospheric program on the Arctic Ocean Expedition in the summer 
of 1996 (AOE-96) - A Technical Overview - Outline of experimental approach, instruments, scientific objectives, J. Geophys. Res., 106, 32051-32067, 2001.

Lee, L. A., Carslaw, K. S., Pringle, K. J., and Mann, G. W.: Mapping the uncertainty in global CCN using emulation, Atmos. Chem. Phys., 12, 9739-9751, doi:10.5194/acp-12-9739-2012, 2012.

Liu, Y. H., Key, J. R., Liu, Z. Y., Wang, X. J., and Vavrus, S. J.: A cloudier Arctic expected with diminishing sea ice, Geophys. Res. Lett., 39, L05705, doi:10.1029/2012GL051251, 2012.

Lohmann, U. and Leck, C.: Importance of submicron surface-active organic aerosols for pristine Arctic clouds, Tellus B, 57B, 261268, 2005.

Mann, G. W., Carslaw, K. S., Spracklen, D. V., Ridley, D. A., Manktelow, P. T., Chipperfield, M. P., Pickering, S. J., and Johnson, C. E.: Description and evaluation of GLOMAP-mode: a modal global aerosol microphysics model for the UKCA composition-climate model, Geosci. Model Dev., 3, 519-551, doi:10.5194/gmd-3-519-2010, 2010.

Martin, M., Chang, R. Y.-W., Sierau, B., Sjogren, S., Swietlicki, E., Abbatt, J. P. D., Leck, C., and Lohmann, U.: Cloud condensation nuclei closure study on summer arctic aerosol, Atmos. Chem. Phys., 11, 11335-11350, doi:10.5194/acp-11-11335-2011, 2011.

Mauritsen, T., Sedlar, J., Tjernström, M., Leck, C., Martin, M., Shupe, M., Sjogren, S., Sierau, B., Persson, P. O. G., Brooks, I. M., and Swietlicki, E.: An Arctic CCN-limited cloud-aerosol regime, Atmos. Chem. Phys., 11, 165-173, doi:10.5194/acp-11165-2011, 2011.

Nightingale, P. D., Malin, G., Law, C. S., Watson, A. J., Liss, P. S., Liddicoat, M. I., Boutin, J., and Upstill-Goddard, R. C.: In situ evaluation of air-gas exchange parameterizations using novel conservative and volatile tracers, Global Biogeochem. Cy., 14, 373-387, doi:10.1029/1999GB900091, 2000.

Orellana, M. V., Matrai, P. A., Leck, C., Rauschenberg, C. D., and Lee, A. M.: Marine microgels as a source of cloud condensation nuclei in the high Arctic, P. Natl. Acad. Sci. USA, 108, 1361213617, 2011.

Paatero, J., Vaattovaara, P., Vestenius, M., Meinander, O., Makkonen, U., Kivi, R., Hyvärinen, A., Asmi, E., Tjernström, M., and Leck, C.: Finnish contribution to the Arctic summer cloud ocean study (ascos) expedition, arctic ocean 2008, Geophysica, 45, 119-146, 2009.

Pratt, K. A., Custard, K. D., Shepson, P. B., Douglas, T. A., Pohler, D., General, S., Zielcke, J., Simpson, W. R., Platt, U., Tanner, D. J. Huey, L. G., Carlsen, M., and Stirm, B. H. : Photochemical production of molecular bromine in Arctic surface snowpacks, Nat. Geosci., 6, 351-356, doi:10.1038/NGEO1779, 2013.

Quinn, P. K. and Bates, T. S.: The case against climate regulation via oceanic phytoplankton sulphur emissions, Nature, 480, 5156, doi:10.1038/nature10580, 2011.

Rayner, N. A., Parker, D. E., Horton, E. B., Folland, C. K., Alexander, L. V., and Rowell, D. P.: Global analyses of sea surface temperature, sea ice, and night marine air temperature since the late nineteenth century, J. Geophys. Res., 108, 4407, doi:10.1029/2002JD002670, 2003.

Rempillo, O., Seguin, A. M., Norman, A.-L., Scarratt, M., Michaud, S., Chang, R., Sjostedt, S., Abbatt, J., Else, B., Papakyriakou, T., Sharma, S., Grasby, S., and Levasseur, M.: Dimethyl sulfide air-sea fluxes and biogenic sulfur as a source of new aerosols in the Arctic fall, J. Geophys. Res., 116, D00S04, doi:10.1029/2011JD016336, 2011.

Roberts, G. C. and Nenes, A. A.: A continuous-flow streamwise thermal-gradient $\mathrm{CCN}$ chamber for atmospheric measurements, Aerosol Sci. Technol., 39, 206-221, doi:10.1080/027868290913988, 2005.

Scott, C. E., Rap, A., Spracklen, D. V., Forster, P. M., Carslaw, K. S., Mann, G. W., Pringle, K. J., Kivekäs, N., Kulmala, M., Lihavainen, H., and Tunved, P.: The direct and indirect radiative effects of biogenic secondary organic aerosol, Atmos. Chem. Phys., 14, 447-470, doi:10.5194/acp-14-447-2014, 2014.

Sedlar, J., Tjernström, M., Mauritsen, T., Shupe, M. D., Brooks, I. M., Persson, P. O. G., Birch, C. E., Leck, C., Sirevaag, A., and Nicolaus, M.: A transitioning arctic surface energy budget: the impacts of solar zenith angle, surface albedo and cloud radiative forcing, Clim. Dynam., 37, 1643-1660, doi:10.1007/s00382010-0937-5, 2011.

Shindell, D. T., Chin, M., Dentener, F., Doherty, R. M., Faluvegi, G., Fiore, A. M., Hess, P., Koch, D. M., MacKenzie, I. A., Sanderson, M. G., Schultz, M. G., Schulz, M., Stevenson, D. S., Teich, H., Textor, C., Wild, O., Bergmann, D. J., Bey, I., Bian, H., Cuvelier, C., Duncan, B. N., Folberth, G., Horowitz, L. W., Jonson, J., Kaminski, J. W., Marmer, E., Park, R., Pringle, K. J., Schroeder, S., Szopa, S., Takemura, T., Zeng, G., Keating, T. J., and Zuber, A.: A multi-model assessment of pollution transport to the Arctic, Atmos. Chem. Phys., 8, 5353-5372, doi:10.5194/acp-85353-2008, 2008.

Spracklen, D. V., Pringle, K. J., Carslaw, K. S., Chipperfield, M. P., and Mann, G. W.: A global off-line model of sizeresolved aerosol microphysics: I. Model development and prediction of aerosol properties, Atmos. Chem. Phys., 5, 2227 2252, doi:10.5194/acp-5-2227-2005, 2005.

Struthers, H., Ekman, A. M. L., Glantz, P., Iversen, T., Kirkevåg, A., Mårtensson, E. M., Seland, Ø., and Nilsson, E. D.: The effect of sea ice loss on sea salt aerosol concentrations and the radiative balance in the Arctic, Atmos. Chem. Phys., 11, 3459-3477, doi:10.5194/acp-11-3459-2011, 2011.

Tjernström, M., Birch, C. E., Brooks, I. M., Shupe, M. D., Persson, P. O. G., Sedlar, J., Mauritsen, T., Leck, C., Paatero, J., Szczodrak, M., and Wheeler, C. R.: Meteorological conditions in the central Arctic summer during the Arctic Summer Cloud Ocean Study (ASCOS), Atmos. Chem. Phys., 12, 6863-6889, doi:10.5194/acp-12-6863-2012, 2012.

Tjernström, M., Leck, C., Birch, C. E., Bottenheim, J. W., Brooks, B. J., Brooks, I. M., Bäcklin, L., Chang, R. Y.-W., de Leeuw, G., Di Liberto, L., de la Rosa, S., Granath, E., Graus, M., Hansel, A., Heintzenberg, J., Held, A., Hind, A., Johnston, P., Knulst, J., Martin, M., Matrai, P. A., Mauritsen, T., Müller, M., Norris, S. J., Orellana, M. V., Orsini, D. A., Paatero, J., Persson, P. O. G., Gao, Q., Rauschenberg, C., Ristovski, Z., Sedlar, J., Shupe, M. D., Sierau, B., Sirevaag, A., Sjogren, S., Stetzer, O., Swietlicki, E., Szczodrak, M., Vaattovaara, P., Wahlberg, N., Westberg, M., and Wheeler, C. R.: The Arctic Summer Cloud Ocean Study (ASCOS): overview and experimental design, Atmos. Chem. Phys., 14, 2823-2869, doi:10.5194/acp-14-2823-2014, 2014.

van der Werf, G. R., Randerson, J. T., Giglio, L., Collatz, G. J., Mu, M., Kasibhatla, P. S., Morton, D. C., DeFries, R. S., Jin, Y., and van Leeuwen, T. T.: Global fire emissions and the contribution of deforestation, savanna, forest, agricultural, and 
peat fires (1997-2009), Atmos. Chem. Phys., 10, 11707-11735, doi:10.5194/acp-10-11707-2010, 2010.

Vavrus, S., Bhatt, U. S., and Alexeev, V. A.: Factors influencing simulated changes in future Arctic cloudiness, J. Climate, 24, 48174830, doi:10.1175/2011JCLI4029.1, 2011.

Voulgarakis, A., Yang, X., and Pyle, J. A.: How different would tropospheric oxidation be over an ice-free Arctic?, Geophys. Res. Lett., 36, L23807, doi:10.1029/2009GL040541, 2009.

Wassmann, P. and Reigstad, M.: Future Arctic Ocean seasonal ice zones and implications for pelagic-benthic coupling, Oceanography, 24, 220-231, 2011.

Woodhouse, M. T., Carslaw, K. S., Mann, G. W., Vallina, S. M., Vogt, M., Halloran, P. R., and Boucher, O.: Low sensitivity of cloud condensation nuclei to changes in the sea-air flux of dimethyl-sulphide, Atmos. Chem. Phys., 10, 7545-7559, doi:10.5194/acp-10-7545-2010, 2010.
Woodhouse, M. T., Mann, G. W., Carslaw, K. S., and Boucher, O.: Sensitivity of cloud condensation nuclei to regional changes in dimethyl-sulphide emissions, Atmos. Chem. Phys., 13, 2723 2733, doi:10.5194/acp-13-2723-2013, 2013.

Yang, X., Pyle, J. A., and Cox, R. A.: Sea salt aerosol production and bromine release: Role of snow on sea-ice, Geophys. Res. Lett., 35, L16815, doi:10.1029/2008GL034536, 2008. 